\title{
Pengaruh Umur Sapih terhadap Performans Babi Duroc Jantan
}

\section{The Effect of Weaning Age on The Performance of Male Duroc Pigs}

\author{
A. L. R. I. Pinem ${ }^{1 *}$, S. N. Aritonang ${ }^{2}$, dan Khasrad ${ }^{2}$ \\ ${ }^{1}$ Program Pascasarjana, Fakultas Peternakan, Universitas Andalas, Padang - Indonesia \\ ${ }^{2}$ Program Studi Peternakan, Fakultas Peternakan, Universitas Andalas, Padang - Indonesia \\ *Corresponding E-mail: pinemraja@yahoo.co.id
}

(Diterima: 13 Oktober 2019; Disetujui: 4 Desember 2019)

\begin{abstract}
ABSTRAK
Penelitian ini bertujuan untuk melihat pengaruh umur sapih terhadap performans babi Duroc jantan. Ternak yang digunakan dalam penelitian ini adalah 18 ekor babi Duroc jantan lepas sapih dengan bobot lahir antara 900 gram - 1300 gram yang berasal dari 3 induk babi yang berbeda dengan litter size 10 ekor. Penelitian ini berupa eksperimen menggunakan Rancangan Acak Lengkap (RAL) dengan 3 perlakuan dan 6 ulangan selama 26 minggu. Perlakuan yang digunakan dalam penelitian ini adalah umur sapih pada babi yaitu 2 minggu (A), 3 minggu (B), dan 4 minggu (C). Peubah yang diamati adalah bobot sapih, bobot hidup, dan berat karkas. Penelitian diawali dengan sanitasi lalu penimbangan bobot awal, kemudian dilakukan pengacakan tempat ternak. Tiap kandang dikelompokkan sesuai umur. Pemberian pakan dilakukan dua kali sehari. Penimbangan sisa pakan dilakukan setiap pagi. Ternak babi dimandikan dua kali sehari dan penimbangan bobot badan dilakukan setiap 2 minggu sekali sampai 5 bulan 2 minggu. Hasil penelitian menunjukkan, umur sapih berpengaruh terhadap performans babi Duroc Jantan. Umur sapih berpengaruh nyata $(\mathrm{P}<0,05)$ terhadap bobot sapih dan bobot hidup, namun tidak berpengaruh terhadap bobot karkas $(\mathrm{P}>0,05)$. Umur sapih 4 minggu memberikan performans yang terbaik dibandingkan umur sapih lainnya.
\end{abstract}

Kata kunci: babi Duroc, performans, umur sapih

\section{ABSTRACT}

This study aims to investigate the effect of weaning age on the performance of male Duroc pigs. This study used 18 weaned Duroc male pigs with birth weights between 900 grams to 1300 grams from 3 sows with 10 head of litter sizes for one sow. This study used an experimental method using a Completely Randomized Design (CRD) with 3 treatments and 6 replications for 26 weeks. The treatments were the age of weaned pigs; 2 weeks (A), 3 weeks (B) and 4 weeks (C). The variables measured were weaning weights, live weights and carcass weights. The study began with sanitation and then weighed the initial weight, then randomized the place of livestock. Each cage is grouped according to age. Feeding is done twice a day. Weighing the remaining food is done every morning. Pigs are bathed twice a day and weighing is done every 2 weeks to 5 months 2 weeks. The results showed that weaning age influenced the performance of male Duroc pigs significantly $(P<0,05)$. Weaning age significantly increased on weaning weight and live weight, but had no effect on carcass weight ( $P>0.05$ ). Weaning age in 4 weeks was the best performance of male duroc pigs.

Keywords: Duroc, performance, pig, weaning age

\section{PENDAHULUAN}

Salah satu dari jenis ternak yang mempunyai potensi sebagai sumber protein hewani yaitu ternak babi yang memiliki sifat- sifat seperti prolifik, efisien dalam mengkonversi bahan makanan menjadi daging dan memiliki persentase karkas yang tinggi serta kualitas daging yang cukup baik (Siagian et al., 2005). Performans seekor ternak babi dapat dilihat dari pertambahan berat badan dan jumlah pakan yang dikonsumsinya. Menurut 
Velayudan et al. (2015) pakan sumber energi dibutuhkan ternak babi untuk fungsi pemeliharaan dan produksi. Dube et al. (2011) mengemukakan bahwa tingkat manajemen peternakan babi yang optimum merupakan prasyarat untuk mencapai performans pertumbuhan dan kualitas hasil karkas yang optimum. Faktor yang mempengaruhi performans babi diantaranya adalah umur sapih. Umumnya anak babi disapih pada umur 2 minggu, 3 minggu sampai 6 minggu. Penyapihan yang terlalu dini berpengaruh terhadap anak babi untuk mengkonsumsi air susu sehingga hal ini berkaitan terhadap pertumbuhan untuk mendapatkan bobot sapih yang optimal. Menurut Ardana dan Putra (2008) ada beberapa sistem penyapihan yang biasa dilakukan oleh peternak yaitu sistem penyapihan anak umur 4-6 minggu, umur 3-4 minggu, dan sistem penyapihan dini pada umur 14-19 hari, sedangkan Sinaga (2010) menyatakan lama penyapihan yang dilakukan pada ternak biasanya pada umur 2 bulan tetapi dapat dipersingkat dengan perlakuan tertentu.

Adapun bobot badan anak babi sebelum disapih tergantung terhadap produksi dan kemampuan anak babi untuk mengkonsumsi susu dari induknya. Menurut Nangoy (2015) pada masa prapenyapihan, pertambahan bobot badan anak babi bergantung pada produksi air susu serta kemampuan anak babi untuk konsumsi air susu. Bobot sapih anak babi merupakan indikator dari produksi air susu induknya, serta beberapa faktor yang mempengaruhi bobot sapih antara lain kesehatan anak babi, produksi ai susu induk dan cara pemberian pakan. Tribudi (2018) menyatakan faktor genetik dan kemampuan induk membesarkan anaknya serta pengelolaan selama masa prasapih juga mempengaruhi bobot sapih.

Siagian (1999) menyatakan penyapihan pada umur tertentu, anak babi yang memiliki bobot badan yang tinggi saat disapih akan bertumbuh lebih cepat mencapai bobot pasar dibanding dengan anak babi yang bobot badanya lebih ringan. Bobot yang ringan pada saat anak babi dilahirkan akan menurunkan kualitas karkas, dalam hal ini mempunyai deposisi lemak tinggi dan LEA yang rendah (Bee, 2004). Mourad et al. (2001) dan Mc Meekan (2009) mengemukakan jaringan urat daging, tulang, dan lemak yang mempunyai kecepatan pertumbuhan yang berbeda-beda merupakan komposisi utama dari karkas. Siagian et al. (2005) menyatakan bobot karkas sangat dipengaruhi oleh bobot hidup ternak tersebut, tetapi dengan bobot hidup yang tinggi tidak selalu menghasilkan bobot karkas yang tinggi pula, hal ini disebabkan karena adanya perbedaan bobot dari kepala, darah, bulu, isi rongga perut dan isi rongga dada. Edwards (2003) menyatakan persentase bobot karkas babi Duroc dapat mencapai 74,3 $\%$ dari bobot hidup.

Tujuan penelitian ini untuk mengetahui pengaruh umur sapih terhadap performans babi Duroc yang dimanifestasikan dalam bobot sapih, bobot hidup, dan bobot karkas. Manfaat dari penelitian ini adalah untuk memberikan informasi kepada peternak atau pengusaha babi tentang pengaruh umur sapih dalam menghasilkan performans babi Duroc yang terbaik.

\section{METODE}

\section{Materi Penelitian}

Ternak yang digunakan 18 ekor anak babi Duroc jantan dengan bobot lahir antara 900 gram - 1.300 gram yang berasal dari 3 induk babi, masing-masing dengan litter size 10 ekor. Bahan yang digunakan yaitu yang terdiri dari dedak jagung, dedak padi, kosentrat Gold Coin 805, pakan butiran 550, dan 551. Komposisi ransum yang diberikan dapat dilihat pada Tabel 1. Bahan kimia yang digunakan Tysinol, Sulpig, obat cacing dan Vitamin B kompleks. Peralatan yang digunakan adalah timbangan duduk 100 $\mathrm{kg}$, timbangan gantung, timbangan kecil (2 $\mathrm{kg}$ ), tempat pakan, pita ukur, jangka sorong keranjang dan pig nipple. Penelitian ini adalah penelitian eksperimen dengan menggunakan Rancangan Acak Lengkap (RAL) yang terdiri 
Tabel 1. Nutrisi ransum babi

\begin{tabular}{lccc}
\hline Zat Makanan & Starter & Grower & Finisher \\
\hline Air (\%) & 11,590 & 12,380 & 12,710 \\
BK (\%) & 88,410 & 87,620 & 87,290 \\
PK (\%) & 18,950 & 17,170 & 17,000 \\
LK (\%) & 1,700 & 3,830 & 2,910 \\
SK (\%) & 2,440 & 5,330 & 4,030 \\
Abu (\%) & 5,900 & 5,240 & 5,020 \\
Ca (\%) & 0,096 & 0,094 & 0,186 \\
Phosphor (\%) & 0,905 & 0,334 & 0,772 \\
\hline
\end{tabular}

Sumber: Hasil analisa bahan makanan di Laboratorium Nutrisi Ruminansia Fakultas Peternakan Universitas Andalas Padang

dari 3 perlakuan dan 6 ulangan. Perlakuan tersebut adalah umur sapih anak babi yang terdiri dari 2 minggu (A), 3 minggu (B), dan 4 minggu (C). Variabel yang diukur dalam penelitian ini adalah:

Bobot Sapih: Bobot sapih anak babi, diperoleh dari berat akhir saat akan disapih (gram) ( Hutapea, 2009).

Bobot Hidup: Bobot hidup diperoleh dari hasil penimbangan ternak sewaktu masih hidup setelah dipuasakan selama lebih kurang 12 jam ( Ensminger, 1991).

Bobot Karkas: adalah hasil penimbangan karkas yaitu bagian badan ternak yang telah dipotong dipisahkan bagian kepala, keempat kaki mulai korpus dan tarsus, paru-paru, jantung, dan jeroan (Soeparno, 2005).

\section{Prosedur Penelitian}

Penelitian diawali dengan sanitasi, penimbangan bobot awal dan pengacakan penempatan ternak. Tiap kandang dikelompokkan sesuai umur. Pemberian makanan dilakukan pagi dan sore hari. Penimbangan sisa makanan dilakukan setiap pagi. Ternak babi dimandikan 2 kali sehari. Penimbangan berat badan setiap 2 minggu sekali sampai umur potong 5 bulan 2 minggu.

DData yang diperoleh dianalisis secara statistik dengan analisis keragaman serta perbedaan diantara perlakuan akan diuji dengan uji lanjut berganda Duncan (Steel dan
Torrie, 1993). Hasil yang diperoleh diuji pada taraf kepercayaan $5 \%(\mathrm{P}<0,05)$.

\section{HASIL DAN PEMBAHASAN}

\section{Bobot Sapih}

Hasil analisis keragaman menunjukkan bahwa perlakuan umur penyapihan memberikan pengaruh berbeda nyata $(\mathrm{P}<0,05)$ terhadap bobot sapih babi Duroc, yang berarti umur sapih mempengaruhi bobot sapih babi Duroc (Tabel 2). Bobot sapih yang lebih tinggi babi Duroc yang disapih pada umur 4 minggu disebabkan pemeliharaan selama 4 minggu babi mampu mengkonsumsi air susu dari induknya jauh lebih banyak dibanding babi yang disapih umur 3 dan 2 minggu. Pertumbuhan babi sebelum dilepas dari induknya sangat dipengaruhi dari susu induknya. Akibatnya dari konsumsi susu yang banyak, kebutuhan nutrisi terhadap babi dapat terpenuhi dengan maksimal dan akan mempengaruhi pertumbuhan babi. Seperti yang dikemukakan oleh Kim et al. (2000) dan Valros et al. (2003) bahwa konsumsi air susu dari induk selama pemeliharaan prasapih menentukan pertumbuhan anak babi setelah kelahiran sampai penyapihan.

Adapun susu adalah sumber makanan bagi babi sebelum disapih, dimana susu memiliki kandungan- kandungan nutrisi yang sempurna untuk pertumbuhan babi. Hutapea 
JPI Vol. 22 (1): 73-79

Tabel 2. Rataan bobot sapih, bobot hidup, dan bobot karkas

\begin{tabular}{lccc}
\hline Perlakuan & Bobot Sapih (gr) & Bobot Hidup (kg) & Bobot Karkas (kg) \\
\hline A (2 Minggu) & $3.116,67^{\mathrm{a}}$ & $65,50^{\mathrm{b}}$ & 44,1 \\
B (3 Minggu) & $3.433,33^{\mathrm{a}}$ & $63,83^{\mathrm{b}}$ & 43,8 \\
C (4 Minggu) & $4.016,67^{\mathrm{b}}$ & $72,53^{\mathrm{a}}$ & 48,0 \\
\hline
\end{tabular}

Keterangan: Superskrip yang berbeda menunjukkan berbeda nyata $(\mathrm{P}<0,05)$.

(2009) menyatakan makanan utama yang ideal bagi anak babi pada masa menyusu yang diakui adalah air susu induk babi. Sihombing (1997) mengemukakan bahwa kandungan air susu induk babi setelah 2 hari yaitu $7 \%$ lemak, $6,5 \%$ protein, dan $5 \%$ laktosa. Tribudi (2018) menyatakan produksi susu induk sangat mempengaruhi pertumbuhan setelah lahir.

Bobot sapih yang lebih rendah pada babi Duroc umur 2 minggu (A) disebabkan babi mengkonsumsi air susu yang lebih sedikit dibanding yang disapih pada umur yang lebih lama. Sedikitnya mengkonsumsi susu dari induk babi menyebabkan kebutuhan nutrisi babi Duroc tidak tercukupi sehingga berpengaruh terhadap pertambahan bobot badan babi sebelum disapih. Seperti yang dikemukakan oleh Lapian (2012) pertambahan bobot badan anak babi menyusu bergantung pada kuantitas dan kualitas air susu yang diperoleh dari induknya selama menyusu. Hal ini didukung oleh hasil penelitian Prawirodigdo (1995) dimana babi yang berumur 2 minggu memperoleh bobot badan 3.150 gram.

Pada babi Duroc yang disapih pada umur 3 minggu (B) memiliki bobot sapih yang berbeda tidak nyata $(\mathrm{P}>0,05)$ dengan bobot sapih Duroc yang disapih pada umur 2 minggu (A). Ini disebabkan babi Duroc sampai umur 3 minggu mengkonsumsi susu dengan jumlah yang relatif sama perharinya mengakibatkan asupan nutrisinya tidak berbeda sehingga pertumbuhannya pun sama. Akibatnya pertambahan bobot badan babi sampai disapih pun relatif tidak berbeda. Selain itu kondisi ini juga dapat disebabkan dari faktor induk babi sampai umur 3 minggu setelah melahirkan memproduksi susu dengan jumlah yang tidak banyak sehingga diminggu ke 3 babi Duroc mengkonsumsi susu masih terbatas dan tidak berbeda nyata dengan babi yang disapih umur 2 minggu. Seperti yang dikemukakan oleh Parakkasi (1990) produksi air susu induk babi dapat diukur secara tidak langsung yaitu berdasarkan bobot badan pada anak-anaknya. Anak babi ditimbang sebelum dan segera sesudah menyusu, selisih berat penimbangan adalah produksi susu saat itu.

Kondisi ini disebabkan babi dalam pertumbuhan sebelum disapih tergantung pada produksi susu induk. Seperti yang dikemukakan oleh Lapian (2012) bahwa pertambahan bobot badan anak babi prapenyapihan bergantung pada produksi air susu induk babi dan kemampuan anak babi untuk menyusu. Produksi air susu induk babi per menyusui sangat penting terhadap anak babi, terutama pada saat awal laktasi ketika anak babi sepenuhnya bergantung pada air susu induknya, sebelum anak babi tersebut belajar megkonsumsi makanan dari sumber yang lain, seperti ransum. Jika anak babi tidak dapat memanfaatkan air susu induk pada awal laktasi secara maksimal maka akan menyebakan pertumbuhan dan perkembangannya terganggu. Hasil penelitian Silalahi (2011) menunjukkan bahwa perbedaan umur penyapihan pada anak babi berpengaruh terhadap bobot sapih. Kemampuan dan persaingan untuk menyusu, dan kemampuan bertahan hidup merupakan kontribusi yang utama dalam masa prasapih sampai usia pascasapih (Zindove et al., 2014).

\section{Bobot Hidup}

Hasil analisis keragaman memperlihatkan bahwa perlakuan umur penyapihan memberikan pengaruh berbeda 
nyata $(\mathrm{P}<0,05)$ terhadap bobot hidup babi Duroc saat sudah mencapai umur potong (Tabel 2). Tingginya berat bobot hidup dari babi Duroc yang disapih pada umur 4 minggu (C) disebabkan jumlah konsumi ransum selama penelitian lebih banyak sehingga pertambahan bobot badan hariannya pun lebih besar dari pada perlakuan lainnya yang diikuti oleh bobot tubuh yang paling besar juga saat dipotong. Hal ini sesuai dengan pernyataan Siagian et al. (2005) yang menyatakan bahwa bobot hidup seekor ternak akan berbeda-beda seiring dengan adanya pemberian pakan yang berbeda pula.

Perbedaan bobot hidup tersebut disebabkan adanya perbedaan pertambahan bobot badan harian, rataan pakan yang dikonsumsi masing-masing individu, jumlah pertambahan otot tiap hari serta perbedaan jumlah lemak yang telah disimpan dalam tubuh. Hal ini didukung oleh hasil penelitian Lee et al. (2010) pertambahan bobot badan harian yang tinggi akan menghasilkan bobot potong yang tinggi. Seperti yang tampil pada hasil penelitian ini, babi Duroc jantan yang disapih umur 4 minggu mengkonsumsi ransum dalam jumlah yang banyak dan disertai dengan pertambahan bobot badan yang tinggi yang diikuti oleh bobot badan yang paling tinggi saat dipotong.

Babi Duroc yang disapih pada umur 2 minggu (A) memiliki bobot hidup yang lebih rendah dan berbeda tidak nyata dengan bobot hidup babi Duroc yang disapih umur 3 minggu. Rendahnya bobot hidup ini disebabkan babi Duroc umur 2 minggu mengkonsumsi ransum dengan jumlah yang sedikit karena bobot awal babi pada saat disapih lebih kecil. Hal ini sesuai dengan pendapat Sihombing (2006) yang menyatakan laju pertumbuhan babi sangat dipengaruhi oleh berat sapih. Anak babi dengan berat sapihnya besar akan bertumbuh lebih cepat dan membutuhkan waktu yang lebih singkat untuk mencapai bobot potong dibanding anak babi dengan berat sapihnya lebih kecil.

Konsumsi ransum yang lebih sedikit pada babi Duroc yang disapih umur 2 minggu mengakibatkan kebutuhan-kebutuhan gizi dalam tubuh kurang mencukupi sehingga berpengaruh terhadap pertumbuhan dan pertambahan bobot badan harian yang rendah. Akibatnya bobot hidup babi yang disapih umur 2 minggu paling rendah. Sesuai yang dikemukakan oleh Blakely and Blade (1998) bahwa tingkat konsumsi pakan berpengaruh terhadap laju pertumbuhan dan bobot akhir ternak, karena pembentukan bobot, bentuk dan komposisi tubuh pada hakekatnya adalah merupakan akumulasi dari pakan yang dikonsumsi dalam tubuh ternak.

\section{Bobot Karkas}

Bobot karkas dari babi Duroc pada umur sapih yang berbeda satu sama lain saling berbeda tidak nyata (Tabel 2). Karkas merupakan bagian dari tubuh ternak yang tertinggal setelah kepala, kaki, darah, kulit, saluran pencernaan, intestin, kantong urin, jantung, paru-paru, ginjal, limfa, hati, trakhea, dan jaringan lemak (yang melekat pada bagian tubuh tersebut) diambil. Bagian karkas terdiri atas urat daging dan jaringan lemak, tulang serta residu yang terdiri atas tendon dan jaringan pengikat lainnya, pembuluh darah besar dan lain- lain.

Babi Duroc yang disapih pada umur 4 minggu memiliki bobot hidup yang tinggi sehingga organ-organ tubuh pada babi juga meningkat. Seperti yang dikemukakan oleh Hardiawan et al. (2015) bahwa bobot tubuh babi yang meningkat menyebabkan berat organ juga meningkat. Hal ini dapat dilihat pada hasil penelitian dimana bobot kepala pada babi yang disapih umur 4 minggu $(5,2$ $\mathrm{kg}), 3$ minggu (4,9 kg), dan 2 minggu (4,8 $\mathrm{kg})$. Darah babi pada babi yang disapih umur 4 minggu (3.500 kg), 3 minggu ( $3.000 \mathrm{~kg}$ ), dan 2 minggu ( $3.000 \mathrm{~kg})$. Paru-paru pada babi yang disapih umur 4 minggu $(1,2 \mathrm{~kg}), 3$ minggu $(0,79 \mathrm{~kg})$, dan 2 minggu $(0,8 \mathrm{~kg})$.

Dengan adanya perbedaan terhadap besarnya bobot dan ukuran bagian-bagian non karkas seperti kepala, darah, kaki, dan isi rongga dada pada babi Duroc, mengakibatkan bobot karkas berbeda tidak nyata dengan 
bobot karkas babi Duroc umur 3 dan 2 minggu. Hal ini didukung oleh Siagian et al. (2005) yang menyatakan bahwa bobot karkas sangat dipengaruhi oleh bobot hidup dari ternak tersebut, tetapi bobot hidup yang tinggi tidak selalu menghasilkan bobot karkas yang tinggi pula, ini dikarenakan adanya perbedaan ukuran dan berat dari kepala, isi rongga perut, isi rongga dada, darah dan bulu.

\section{KESIMPULAN}

Berdasarkan hasil penelitian dapat disimpulkan bahwa umur sapih yang berbeda berpengaruh terhadap bobot sapih, bobot hidup, namun tidak berpengaruh bobot karkas. Umur sapih 4 minggu memiliki performans yang baik dibandingkan umur sapih lainnya.

\section{DAFTAR PUSTAKA}

Ardana, I. dan Putra, H. 2008. Manajemen Reproduksi, Produksi, dan Penyakit Ternak Babi. Bali: Udayana University Press.

Bee, G. 2004.EffectofEarly GestationFeeding, Birth Weight and Gender of Progeny on Muscle Fiber Characteristics. Journal of Animal Science, 82(3), 826-836.

Blakely, J. dan Bade, D. 1998. Ilmu Peternakan. Yogyakarta: Universitas Gajah Mada Press.

Dube, B., Mulugeta, S., Westhuizen, V. D. dan Dzama, K. 2011. Non- Genetic Factors Affecting Growth Performance and Carcass Characteristics of Two South African Pig Breeds. South African Journal of Animal Science, 41(2), 162174.

Edwards, D., Bates, R. and Osburn, W. 2003. Evaluations of Duroc vs Pietrainsired Pigs for Carcass and Meat Quality Measures. Journal of Animal Science, 81(8), 1895-1899.

Ensminger, M. 1991. Animal Science. The Interstate Printes and Publisher. Inc.
Denville, Illionis.

Hardiawan, N., Mahardika, I. G. dan Astawa, P. 2015. Pengaruh Pemberian Ekstrak Kunyit (Curcuminoid) dalam Ransum terhadap Organ Dalam Babi . Journal of Tropical Animal Science, 3(3), 492500.

Hutapea, I. 2009. Penampilan Anak Babi Menyusu dari Induk dengan Ransum yang Mengandung Tepung Daun Bangunbangun (Coleus amboinicus Lour) pada Taraf yang Berbeda. Bogor: Institut Pertanian Bogor.

Kim, S., W. L, H., I. K., H. and R. A. E. 2000. Growth of Nursing Pigs Related to the Characteristics of Nursed Mammary Glands. Journal of Animal Science, 78(5), 1313-1318.

Lapian, M. 2012. Performans Bakalan dari Induk Babi Melalui Ovulasi Ganda dengan PMSG dan HCG sebelum Pengawinan. Bogor: Institut Pertanian Bogor.

Lee, J., Kim, J., Jin, J. and Han, I. K. 2010. Effect of Phase Feeding on the Growth Performance, Nutrient Utilization and Carcass Characteristics in Finishing Pigs Pork Production. Asian-Aus Journal Animal Science, 13(8), 11371146.

Mc Meekan, C. 2009. The Nature and Variability of the Carcass Characters in Danish and English Bacon Pigs. Journal of Agricultural Science, 29(1), 131-141.

Mourad, M., Gbanamau, G. and Balde, L. 2001. Carcass Characteristics of West Africa Dwarf Goats Under Extensive System. Small Ruminian Research, 42(1), 81-85.

Nangoy, M. M., Najoan, M. dan Soputan. 2015. Pengaruh Bobot Lahir dengan Penampilan Anak Babi sampai Disapih. Jurnal Zootek, 35(1), 138-150.

Parakkasi, A. 1990. Ilmu Gizi Makanan Ternak Monogastrik. Bandung: 
Penerbit Angkasa..

Prawirodigdo, H., Soedarsono, R. and Mujoko, S. 1995. Pertumbuhan Anak Periode Menyusu pada Paritas Pertama. Hemera Zoa, 77(2), 78-87.

Siagian, P. H. dan Natasasmita, S. S. 2005. Pengaruh Substitusi Jagung dengan Corn Gluten Feed (CGF) dalam Ransum Terhadap Kualitas Karkas Babi dan Analisis Ekonomi. Jurnal Media Peternakan, 28(3), 100-108.

Siagian, P. H. 1999. Manajemen Ternak Babi Bogor: Institut Pertanian Bogor.

Sihombing, D. T. 1997. Ilmu Ternak Babi. Yogyakarta: Gadjah Mada University Press.

Sihombing, D. T. 2006. Ilmu Ternak Babi. $2^{\text {nd }}$ ed.Vol 2. Yogyakarta: Gadjah Mada University Press.

Sinaga, S. dan Martini, S. 2010. Pemberian Berbagai Dosis Curcuminoid pada Ransum Babi Periode Starter Efisiensi Ransum. Jurnal Ilmu Ternak, 10(2), 95101.

Silalahi, P. 2011. Pengaruh Penambahan Tepung Tanaman Bangun-bangun (Coleus amboinicus Lour) dalam Ransum terhadap Penampilan Reproduksi Induk dan Anak Babi Menyusui. Bogor: Fakultas Peternakan Institut Pertanian Bogor.
Steel, R. G. dan Torrie, J. H. 1993. Prinsip dan Prosedur Statistika Suatu Pendekatan Biometrik. Jakarta: Gramedia Pustaka.

Soeparno. 2005. Ilmu dan Teknologi Daging. Yogyakarta: Gadjah Mada University Press.

Tribudi, Y. A. and Tohardi, A. 2018. Estimate heritability of birth and weaning weights of duroc and yorkshire pig. Journal of Tropical Animal Production. 19 (1): 46-52.

Valros, A., M. Rundgren., M. Spinka., H. Saloniemi., L. Rydhmer., F. Hultén., K. Uvnäs-Moberg., M. Tomanék, and P. Krejcí. 2003. Metabolic state of the sow, nursing behaviour and milk production. Livestock Production Science, 79 (23), 55-167.

Velayudhan, D. E., Kim, I. H. and Nyachoti, C. M. 2015. Characterization of dietary energy in swine feed and feed Ingredient: Areview of Recent Research Results. Asian- Australas J .Anim Sci, 28 (1): 1-13.

Zindove, T. J., Dzomba, E. F., Kanengoni, A. T. and Chimonyo, M. 2014. Variation in individual piglet birth weights in a Large White $\times$ Landrace sow herd. South African J Animal Science. 44(1): 80-84. 